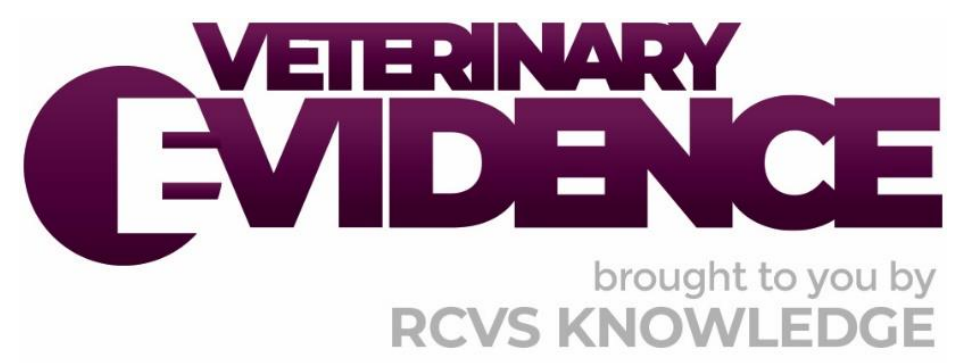

\title{
In dogs undergoing anaesthesia do pre-anaesthetic gastroprotectants reduce gastro-oesophageal reflux?
}

\author{
A Knowledge Summary by
}

Leanne June Barry RVN Cert VNECC PgCert APVN ${ }^{1 *}$

\footnotetext{
${ }^{1}$ University of Glasgow, Glasgow, G12 8QQ

*Corresponding Author (leanne barry@hotmail.com)
}

ISSN: 2396-9776

Published: 12 Nov 2020

in: The Veterinary Evidence journal Vol 5, Issue 4

\author{
DOI: 10.18849/VE.V5I4.340
}

Reviewed by: Zofia Lisowski (BVSc PhD AFHEA MRCVS) and James Swann (MA VetMB DACVIM DECVIM MRCVS)

Next Review Date: 14 May 2022 


\section{KNOWLEDGE SUMMARY}

\section{PICO question}

In dogs undergoing anaesthesia do pre-anaesthetic gastroprotectants reduce gastro-oesophageal reflux?

\section{Clinical bottom line}

\section{Category of research question}

\section{Treatment}

\section{The number and type of study designs reviewed}

Five papers were critically reviewed. There was a randomised prospective study, two randomised blinded prospective studies, randomised non-blinded prospective study and a randomised, double blinded and placebo-controlled prospective study

\section{Strength of evidence}

Moderate

\section{Outcomes reported}

Evidence of high quality suggests omeprazole or cisapride with esomeprazole decrease the incidence of gastro-oesophageal reflux (GOR) in the anaesthetised dog. In addition, a study of lower quality showed that continuous infusion of metoclopramide at a higher than normal dose rate decreased the incidence of GOR

\section{Conclusion}

Omeprazole or cisapride with esomeprazole decreases the incidence of GOR in the anaesthetised dog

\section{How to apply this evidence in practice}

The application of evidence into practice should take into account multiple factors, not limited to: individual clinical expertise, patient's circumstances and owners' values, country, location or clinic where you work, the individual case in front of you, the availability of therapies and resources.

Knowledge Summaries are a resource to help reinforce or inform decision-making. They do not override the responsibility or judgement of the practitioner to do what is best for the animal in their care

\section{Clinical Scenario}

A 5-year-old Labrador undergoing elective arthroscopy under general anaesthesia developed regurgitation and nausea following recovery from anaesthesia. The dog was otherwise healthy with no history of vomiting or regurgitation. The dog developed oesophagitis as a complication of this. Does the administration of preanaesthetic gastroprotectants reduce the risk of GOR? 


\section{The evidence}

There is evidence to support that pre-anaesthetic gastroprotectants prevent GOR. The peer-reviewed studies are generally prospective studies. There is no consistency between the trials of patient sex, breed, depth of anaesthesia, surgery being performed and position during surgery. The choice of anaesthetic drugs can also influence the risk of GOR.

Panti et al. (2009) studied the effects of omeprazole administration pre-operatively on 47 dogs undergoing orthopaedic surgery. Compared to the control group, the dogs that received pre-operative omeprazole had a significant decrease in the occurrence of GOR. In contrast, Zacuto et al. (2012) found that esomeprazole (an isomer of omeprazole) had no effect on GOR. However, cisapride with esomeprazole decreased reflux events. The study by Favarato et al. (2012) evaluated metoclopramide or ranitidine on 90 anaesthetised dogs and concluded that there was no influence on the effect of GOR. However, Wilson et al. (2006) concluded that whilst a low dose of metoclopramide had no effect on the incidence of GOR, administering a higher than normal dose of metoclopramide as a continuous infusion resulted in a $54 \%$ reduction in relative risk of developing GOR. Although the same dose rates of metoclopramide were used for both studies they produced conflicting results. In the study by Johnson (2014) the administration of maropitant in 26 dogs undergoing surgery showed that it prevented vomiting but not the occurrence of GOR.

The gastroprotectant used should be tailored to the patient and the clinical scenario presented (Marks et al., 2018).

\section{Summary of the evidence}

\begin{tabular}{|c|c|}
\hline \multicolumn{2}{|l|}{ Favarato et al. (2012) } \\
\hline Population: & $\begin{array}{l}\text { - Healthy female dogs undergoing general anaesthesia for } \\
\text { ovariosalpingohysterectomy. } \\
\text { - Age range } 0.5-9 \text { years. } \\
\text { - Weight range } 1.5-34 \mathrm{~kg} \text {. }\end{array}$ \\
\hline Sample size: & 90 dogs \\
\hline Intervention details: & $\begin{array}{l}\text { - } 30 \text { dogs were the control group - received only the } \\
\text { anaesthetic protocol. } \\
\text { - } 30 \text { dogs received metoclopramide - an intravenous bolus of } \\
1 \mathrm{mg} / \mathrm{kg} 5 \mathrm{minutes} \text { before induction, and continuous } \\
\text { infusion (1 } \mathrm{mg} / \mathrm{kg} / \mathrm{h} \text { intravenously) immediately after } \\
\text { anaesthetic induction. } \\
\text { - } 30 \text { dogs received ranitidine - intravenous bolus of } 2 \mathrm{mg} / \mathrm{kg} \text {, } \\
6 \text { hours before anaesthesia. } \\
\text { - All dogs received acepromazine }(0.1 \mathrm{mg} / \mathrm{kg}) \text {, propofol (6 } \\
\text { - } \mathrm{mg} / \mathrm{kg}) \text { and isoflurane for anaesthetic protocol. } \\
\text { - Dogs were randomly assigned to groups. }\end{array}$ \\
\hline Study design: & Randomised prospective study \\
\hline Outcome studied: & $\begin{array}{l}\text { Evaluation of metoclopramide or ranitidine on the number } \\
\text { of acid and non-acid reflux events during anaesthesia in } \\
\text { dogs. Oesophageal pH values were monitored using } \\
\text { intraluminal oesophageal pHmetry placed cranially to the } \\
\text { oesophagogastric junction and recorded throughout the } \\
\text { procedure. }\end{array}$ \\
\hline
\end{tabular}




\begin{tabular}{|c|c|}
\hline & $\begin{array}{l}\text { - pH values lower than } 4 \text { was considered an acid reflux } \\
\text { episode. A non-acid reflux was confirmed by } \\
\text { oesophagoscopy immediately after surgery. } \\
\text { - Chi-squared test was used to compare the frequency of GOR } \\
\text { events between groups. }\end{array}$ \\
\hline $\begin{array}{l}\text { Main findings: } \\
\text { (relevant to PICO question): }\end{array}$ & $\begin{array}{l}\text { - Reflux episodes were presented in seven dogs: } \\
\circ \text { Control group }-4 / 30 \text { dogs; } \\
\circ \text { Ranitidine group }-2 / 30 \text { dogs; } \\
\circ \text { Metoclopramide group }-1 / 30 \text { dog. } \\
\text { - Pre-anaesthetic metoclopramide and ranitidine did not } \\
\text { reduce GOR. } \\
\text { - No difference of reflux episodes ( } p>0.05 \text { ) was found } \\
\text { between the groups. }\end{array}$ \\
\hline Limitations: & $\begin{array}{l}\text { - Study was not stated to be blinded. } \\
\text { - Low reflux events in the control group made it difficult to } \\
\text { determine a difference compared to the treatment groups - } \\
\text { a larger sample size could determine a different result. } \\
\text { - Higher doses (more than normally used) of metoclopramide } \\
\text { were used in the study. }\end{array}$ \\
\hline
\end{tabular}

\begin{tabular}{|c|c|}
\hline \multicolumn{2}{|l|}{ Johnson (2014) } \\
\hline Population: & $\begin{array}{l}\text { - Dogs undergoing general anaesthesia for elective soft tissue } \\
\text { or orthopaedic surgery. } \\
\text { - Average age } 3.1 \text { years (range } 6 \text { months to } 10 \text { years). } \\
\text { - } \quad \text { Average weight } 20.5 \mathrm{~kg} \text { (range } 3.6-49.8 \mathrm{~kg} \text { ). } \\
\text { - } \quad \text { No history of vomiting. } \\
\text { - } 18 \text { females and eight males. }\end{array}$ \\
\hline Sample size: & 26 dogs \\
\hline Intervention details: & $\begin{array}{l}\text { - Treatment Group ( } \mathrm{n}=13 \text { dogs) received maropitant } \\
\left(1 \mathrm{mg} / \mathrm{kg}^{-1} \text { ) intravenously (5-7 minutes) } 45-60 \text { minutes }\right. \\
\text { before premedication. } \\
\text { - Control Group ( } \mathrm{n}=13 \text { dogs) received saline } 0.9 \% \\
\left(0.1 \mathrm{~mL} / \mathrm{kg}^{-1}\right) \text { intravenously ( } 5-7 \text { minutes) } 45-60 \text { minutes } \\
\text { before premedication. } \\
\text { - Premedication consisted of hydromorphone }\left(0.1 \mathrm{mg} / \mathrm{kg}^{-1}\right) \\
\text { and acepromazine }\left(0.03 \mathrm{mg} / \mathrm{kg}^{-1}\right) \text { intramuscularly followed } \\
\left.\text { by propofol ( } 2-6 \mathrm{mg} / \mathrm{kg}^{-1}\right) \text { and isoflurane ( } 19 \text { dogs) and } \\
\text { sevoflurane (seven dogs) for anaesthesia. } \\
\text { - Food, not water was withheld for } 12 \text { hours before } \\
\text { anaesthesia. } \\
\text { - Dogs were randomly assigned to groups. } \\
\text { Observer blinded to treatment monitored for retching or } \\
\text { vomiting before induction. }\end{array}$ \\
\hline Study design: & Randomised and blinded prospective study \\
\hline
\end{tabular}




\begin{tabular}{|c|c|}
\hline Outcome studied: & $\begin{array}{l}\text { Objective study to evaluate the efficacy of maropitant for } \\
\text { prevention of vomiting and GOR in dogs undergoing anaesthesia } \\
\text { measuring oesophageal pH } \\
\text { - Flexible oesophageal pH probe placed into distal oesophagus } \\
\text { (measured to assume tip was near gastro-oesophageal } \\
\text { junction) detected for GOR. } \\
\text { - Measurements were taken using a pH recorder and } \\
\text { - uploaded at study completion. } \\
\text { - GOR defined as a pH less than } 4 \text { for gastric acid reflux or } \\
\text { more than } 7.5 \mathrm{pH} \text { for bile reflux for around } 30 \text { seconds. } \\
\text { Initial pH values were measured immediately on probe } \\
\text { placement. } \\
\text { The Fisher Exact test was used to compare GOR in the } \\
\text { groups. }\end{array}$ \\
\hline $\begin{array}{l}\text { Main findings: } \\
\text { (relevant to PICO question): }\end{array}$ & $\begin{array}{l}\text { Vomiting and retching was prevented in the maropitant } \\
\text { group (Treatment Group - } 0 \text { dogs and Control Group - 6/13 } \\
\text { dogs retched or vomited). } \\
\text { - GOR was not prevented as no difference in frequency } \\
\text { between the groups (Treatment Group - } 4 / 13 \text { dogs and } \\
\text { Control Group - } 6 / 13 \text { dogs had a reflux event). }\end{array}$ \\
\hline Limitations: & $\begin{array}{l}\text { Small sample size - a larger group could have shown a difference } \\
\text { between the control group and the treatment group. }\end{array}$ \\
\hline
\end{tabular}

\begin{tabular}{|c|c|}
\hline \multicolumn{2}{|l|}{ Panti et al. (2009) } \\
\hline Population: & $\begin{array}{l}\text { - Dogs (ASA Risk 1-2, American Society of Anesthesiologists } \\
\text { Classification) undergoing general anaesthesia for pelvic } \\
\text { limb orthopaedic surgery. } \\
\text { - Weight range 9-85 kg. } \\
\text { - No history of reflux, regurgitation, vomiting or } \\
\text { gastrointestinal disturbances. }\end{array}$ \\
\hline Sample size: & 47 dogs \\
\hline Intervention details: & $\begin{array}{l}\text { - Treatment Group - } 22 \text { dogs were given } 1 \mathrm{mg} / \mathrm{kg} \text { omeprazole } \\
\text { orally (p.o) at least } 4 \text { hours before anaesthesia. } \\
\text { - Control Group - } 25 \text { dogs received only premedication. } \\
\text { - Pre-anaesthetic - acepromazine ( } 0.03 \mathrm{mg} / \mathrm{kg} \text { ) and } \\
\text { methadone }(0.2 \mathrm{mg} / \mathrm{kg} \text { ) intramuscularly followed by } \\
\text { approximately } 4 \mathrm{mg} / \mathrm{kg} \text { propofol intravenously } 1 \text { hour later } \\
\text { and maintained on isoflurane. } \\
\text { - Each dog received an epidural - } 37 \text { dogs received } \\
\text { preservative free morphine and a local anaesthetic and } 10 \\
\text { dogs received preservative free morphine and sterile normal } \\
\text { saline. } \\
\text { - } 31 \text { dogs breathed spontaneously, and } 16 \text { dogs breathed with } \\
\text { a ventilator. } \\
\text { - Clinician (not involved in probe placement or anaesthetic) } \\
\text { allocated patient to treatment group using a random } \\
\text { number generator. }\end{array}$ \\
\hline
\end{tabular}




\begin{tabular}{|c|c|}
\hline & 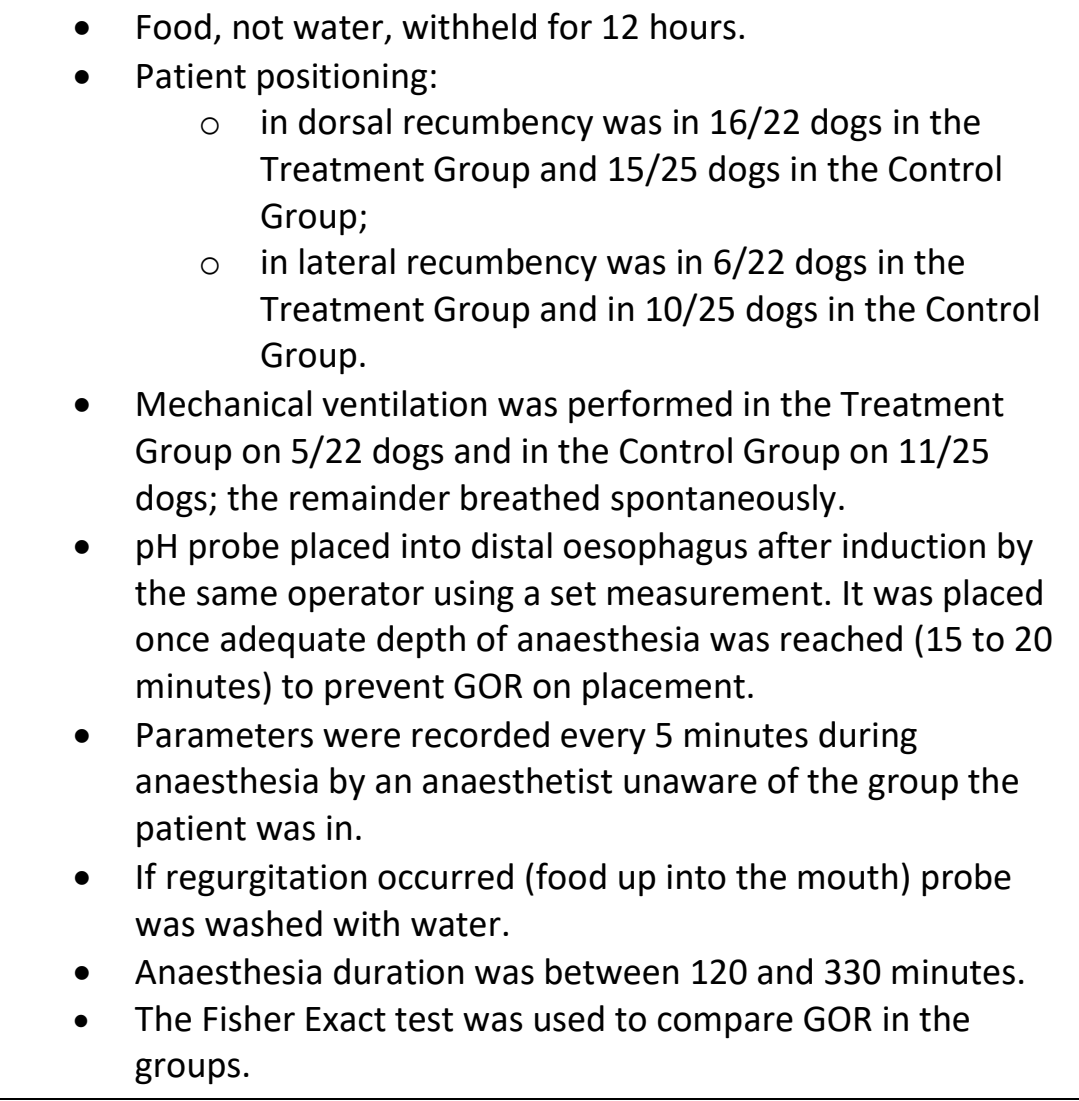 \\
\hline Study design: & Randomised and blinded prospective study \\
\hline Outcome studied: & $\begin{array}{l}\text { - Investigate the effect of pre-operative administration of } \\
\text { omeprazole on oesophageal } \mathrm{pH} \text {. } \\
\text { - } \text { GOR is defined as an abrupt decrease in } \mathrm{pH} \text { below } 4 \text {. }\end{array}$ \\
\hline $\begin{array}{r}\text { Main findings: } \\
\text { (relevant to PICO question): }\end{array}$ & $\begin{array}{l}\text { - GOR was decreased in dogs with the addition of omeprazole. } \\
\text { - Treatment Group }-4 / 22(18 \%) \text { dogs less than } 4 \mathrm{pH} \text {. } \\
\text { - } \text { Control Group }-13 / 25(52 \%) \text { less than } 4 \mathrm{pH} \text {. } \\
\text { - GOR was } 4.7 \text { times more likely in the control group } \\
\text { compared to the treatment groups (logistic regression, } 95 \% \\
\mathrm{Cl} 1.1 \text { to } 24.7, \mathrm{P}=0.032 \text { ). } \\
\text { - The number needed to treat with omeprazole to prevent } \\
\text { GOR was } 2.95(95 \% \mathrm{Cl} 1.69 \text { to } 11.83 \text { ). }\end{array}$ \\
\hline Limitations: & $\begin{array}{l}\text { - Long duration between each anaesthesia. } \\
\text { - Large weight range between dogs. }\end{array}$ \\
\hline
\end{tabular}




\begin{tabular}{|c|c|}
\hline \multicolumn{2}{|l|}{ Wilson et al. (2006) } \\
\hline Population: & $\begin{array}{l}\text { - Healthy dogs undergoing elective orthopaedic surgery. } \\
\text { - Weight }>4.4 \mathrm{~kg} \text {. } \\
\text { - Age over } 6 \text { months. } \\
\text { - Any dogs with a history of dysphagia, regurgitation or } \\
\text { vomiting were excluded. }\end{array}$ \\
\hline Sample size: & 52 dogs \\
\hline Intervention details: & $\begin{array}{l}\text { - Control Group - } 18 \text { dogs received a saline ( } 0.9 \% \text { sodium } \\
\text { chloride (NaCl)) infusion before and during anaesthesia. } \\
\text { - Treatment Group } 1-16 \text { dogs received a low dose } \\
\text { metoclopramide - bolus of } 0.4 \mathrm{mg} / \mathrm{kg} \text { intravenously } \\
\text { followed by a continuous rate infusion of } 0.3 \mathrm{mg} / \mathrm{kg} / \mathrm{hr} \\
\text { before and during anaesthesia. } \\
\text { - Treatment Group } 2-18 \text { dogs received a high dose } \\
\text { metoclopramide - bolus of } 1 \mathrm{mg} / \mathrm{kg} \text { intravenously followed } \\
\text { by a continuous infusion of } 1 \mathrm{mg} / \mathrm{kg} / \mathrm{hr} \text { before and during } \\
\text { anaesthesia. } \\
\text { - Premedication of acepromazine }(0.044 \mathrm{mg} / \mathrm{kg} \text { and morphine } \\
\text { (0.66 mg/kg) intramuscularly, followed by thiopental to } \\
\text { effect and maintained by isoflurane. } \\
\text { - Food was withheld overnight ( } 11-23.5 \text { hours) but water was } \\
\text { available. } \\
\text { Dogs were randomly assigned into groups however } \\
\text { personnel knew their treatment status. } \\
\text { If vomiting occurred ( } 54 \% \text { ), it was recorded following } \\
\text { premedication. } \\
\text { - } \text { All patients were placed into dorsal recumbency. } \\
\text { - Flexible pH probe taped to oesophageal stethoscope was } \\
\text { inserted into oesophagus to measure GOR by } 1 \text { of } 3 \text { trained } \\
\text { people using a standardised placement system. } \\
\text { - Placement was near to gastroesophageal junction and data } \\
\text { continually collected by a computer. } \\
\text { GOR was defined as a pH less than } 4 \text { or more than } 7.5 \text { for } \\
\text { more than } 30 \text { seconds. } \\
\text { groups. }\end{array}$ \\
\hline Study design: & Randomised, non-blinded prospective trial \\
\hline Outcome studied: & $\begin{array}{l}\text { The effect of two doses of metoclopramide on the incidence of GOR } \\
\text { in anaesthetised dogs measuring oesophageal pH. }\end{array}$ \\
\hline $\begin{array}{l}\text { Main findings: } \\
\text { (relevant to PICO question): }\end{array}$ & $\begin{array}{l}\text { - Higher doses of metoclopramide was associated with a } 54 \% \\
\text { reduction in relative risk of developing GOR. } \\
\text { - Dogs that had a GOR episode during anaesthesia: } \\
\circ \text { Control Group - 12/18 dogs; } \\
\circ \text { Treatment Group } 1-7 / 16 \text { dogs; } \\
\circ \text { Treatment Group } 2-6 / 18 \text {. }\end{array}$ \\
\hline Limitations: & $\begin{array}{l}\text { - Morphine was used which could result in increased GOR. } \\
\text { - Study was not blinded. }\end{array}$ \\
\hline
\end{tabular}


- Higher doses (more than normally used - normal range of $0.5 \mathrm{mg}$ to $1 \mathrm{mg} / \mathrm{kg}$ once daily (NOAH, 2020)) of metoclopramide were used in the study.

\begin{tabular}{|c|c|}
\hline \multicolumn{2}{|l|}{ Zacuto et al. (2012) } \\
\hline Population: & $\begin{array}{l}\text { - Healthy dogs undergoing elective orthopaedic surgery. } \\
\text { - Age range } 0.5-12 \text { years. } \\
\text { - } \text { - Peight range } 3.6-52 \mathrm{~kg} \text {. } \\
\text { - All dogs with a history of GOR, regurgitation, vomiting, } \\
\text { oesophagitis or coughing were excluded. }\end{array}$ \\
\hline Sample size: & 61 dogs \\
\hline Intervention details: & 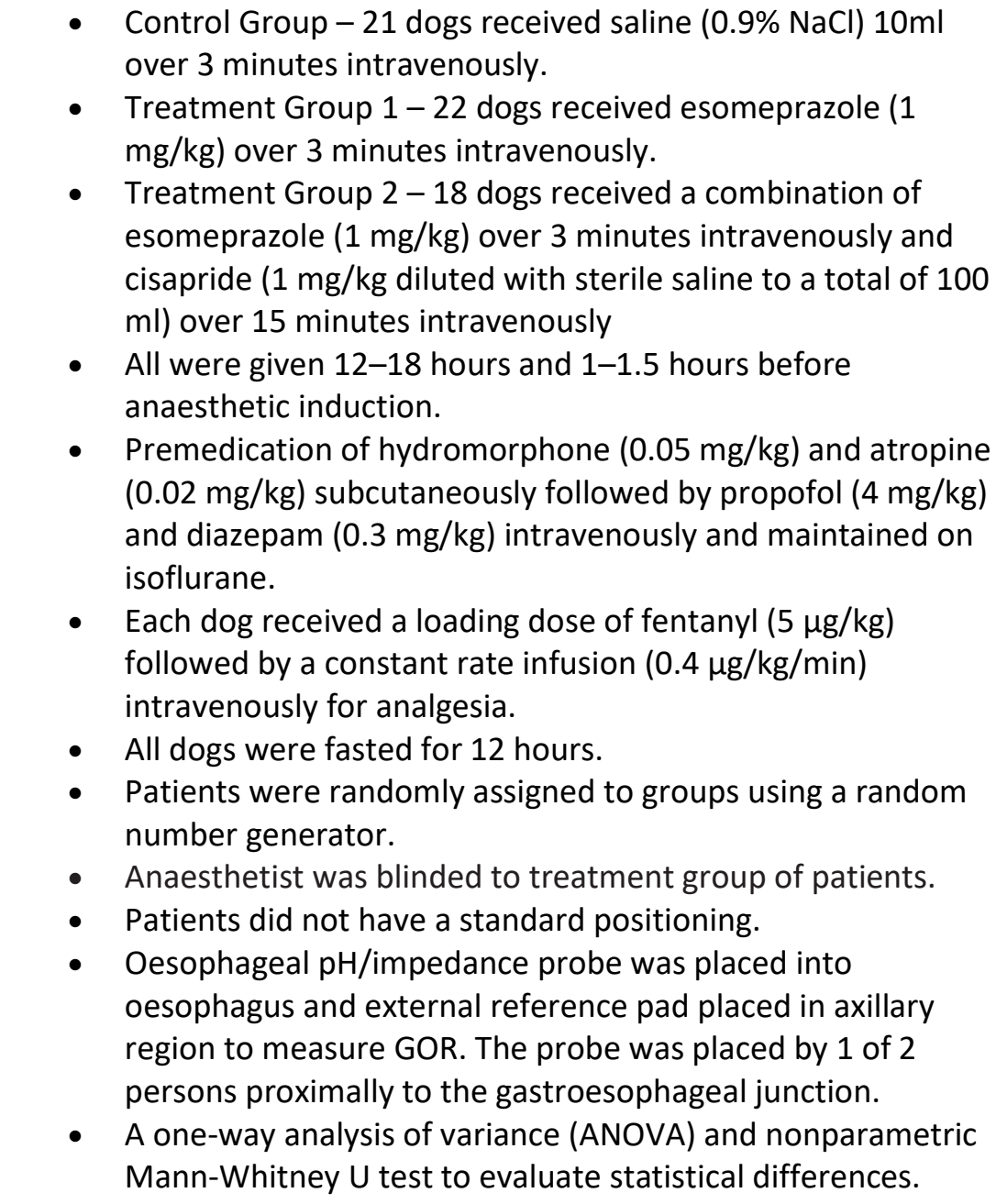 \\
\hline Study design: & $\begin{array}{l}\text { Randomised, double blinded and placebo-controlled prospective } \\
\text { study }\end{array}$ \\
\hline Outcome studied: & $\begin{array}{l}\text { - The influence of esomeprazole and cisapride on } \\
\text { gastroesophageal reflux during anaesthesia in dogs. } \\
\text { - The data was collected via a computer and GOR defined } \\
\text { when the pH was less than } 4 \text {. }\end{array}$ \\
\hline
\end{tabular}




\begin{tabular}{|c|c|c|}
\hline $\begin{array}{l}\text { Main findings: } \\
\text { (relevant to PICO question): }\end{array}$ & \multicolumn{2}{|c|}{$\begin{array}{l}\text { - Preanesthetic administration of cisapride and esomeprazole } \\
\text { decreases the number of reflux events (per dog) in } \\
\text { anesthetised dogs compared to placebo but esomeprazole } \\
\text { alone does not. } \\
\text { - The proportion of dogs having a GOR episode did not differ } \\
\text { significantly among groups. Dogs that showed reflux } \\
\text { episodes in each group: } \\
\circ \text { Control Group } 8 / 21 \text { dogs; } \\
\circ \quad \text { Treatment Group } 18 / 22 \text { dogs; } \\
\circ \quad \text { Treatment Group } 2 \text { 2/18. }\end{array}$} \\
\hline Limitations: & Sma & cip \\
\hline
\end{tabular}

\section{Appraisal, application and reflection}

GOR is common in dogs and studies have shown a range of $12 \%$ to $78.5 \%$ incidences occur under general anaesthesia in studies in referral hospitals (Rodríguez-Alarcón et al., 2015).

The patients in all the studies were fasted of food overnight or for at least 12 hours for consistency and is compatible with a normal clinical setting (Favarato et al., 2012; Johnson, 2014; Panti et al., 2009; Wilson et al., 2006; and Zacuto et al., 2012). The Johnson (2014) study concluded pre-anaesthetic maropitant can assist in reducing vomiting but not the incidence of GOR as the two groups showed a similar GOR event rate. Further studies of a larger group would be required to prove this because the study was underpowered.

A study of preoperative omeprazole was performed by Panti et al. (2009). Results show a significant difference between the control group and the treatment group showing that omeprazole decreases GOR events in the anaesthetised dog. The study uniquely looked at the number needed to treat, showing three dogs would be given omeprazole prophylactically to prevent one of them from having GOR. This study therefore provides a good argument for the prophylactic treatment of all dogs undergoing general anaesthesia.

Morphine was used as an epidural in Panti et al. (2009) and Wilson et al. (2006) used it as a premedication. Morphine has been known to increase GOR when given intramuscularly and so should be avoided in patients undergoing anaesthesia (Wilson et al., 2005).

High doses of metoclopramide trialed by Wilson et al. (2006) in dogs undergoing anaesthesia was associated with a $54 \%$ reduction in relative risk of developing GOR. The study consisted of neutered male dogs and a mixture of spayed and entire female dogs. Although the trial was randomised the study was not blinded. The results do not show a significant difference in low dose metoclopramide. Conversely, a trial by Favarato et al. (2012) using pre-anaesthetic metoclopramide (same dose as Wilson et al. (2006)) or ranitidine concluded no influence in incidence of GOR. The difference between studies was that Wilson et al. (2006) used morphine as a premedication and that could have increased the incidence of GOR showing a discrepancy between the findings. Had morphine been used in Favarato et al. (2012) there is a possibility that a higher GOR event would be present in the control group and may have increased the chances in finding the beneficial effects of metoclopramide or ranitidine. In addition, Favarato et al. (2012) could have been underpowered compared to the Wilson et al. (2006) trial and that could have determined different results.

Esomeprazole with the addition of cisapride (prokinetic drug) has resulted in a decrease in GOR (Zacuto et al., 2012). The trial was randomised with a placebo-control. The difference to the other studies was that it was given 12-18 hours and 1-1.5 hours before anaesthesia. Esomeprazole itself increased the pH significantly but a noticeable difference with cisapride decreased GOR. The patients were not exposed to morphine as per previous studies but were similarly starved for 12 hours. 
A limitation of the studies evaluated is the inclusion of all breeds. Brachycephalic breeds are more susceptible to GOR due to the increase in negative intrathoracic pressure as a result of overcoming upper respiratory tract obstruction associated with brachycephalic obstructive airway syndrome (Downing and Gibson, 2018). Therefore, the inclusion of brachycephalic breeds, which is unknown in these studies may bias the results. It would be prudent for future studies into GOR to consider this breed disposition. Another limitation is that dogs in each study were undergoing either soft tissue or orthopaedic surgery. Patients that undergo abdominal and orthopaedic surgeries are thought to be at higher risk of developing GOR (Rodríguez-Alarcón et al., 2015).

Furthermore, other factors to consider that can increase the incidence of GOR include; the anaesthetic drugs given, patient signalment (breed, sex, age and weight) and positioning of the patient (Rodríguez-Alarcón et al., 2015). Finally, if there was mucosal abutment at the probe tip then this could potentially cause a false negative (Wilson et al., 2006).

In conclusion, studies suggest that high doses of metoclopramide, or omeprazole, or a combination of esomeprazole and cisapride have an effect on reducing GOR episodes in the anaesthetised dog. However, further trials would be beneficial. A new study factoring in trial number, patient positioning, sex, breed and type of surgery being performed could result in supporting previous studies.

\section{Methodology Section}

\begin{tabular}{|c|c|}
\hline \multicolumn{2}{|l|}{ Search Strategy } \\
\hline $\begin{array}{r}\text { Databases searched and dates } \\
\text { covered: }\end{array}$ & $\begin{array}{l}\text { CAB Abstracts on CAB Direct } 1973-2020 \text { Week } 18 \\
\text { PubMed on NCBI interface } 1920 \text { - May } 2020\end{array}$ \\
\hline Search terms: & $\begin{array}{l}\text { CAB Abstracts: } \\
1 \text { (canine or canines or dog or dogs) } \\
2 \text { (anaesthe* or anesthe*) } \\
3 \text { (gastroprotectant* or gastro-protectant* or protectant* or } \\
\text { omeprazole or esomeprazole or cisapride or maropitant or } \\
\text { metoclopramide or ranitidine) } \\
4 \text { (((gastro* or gastric) and reflux) or GOR or GER) } \\
51 \text { and } 2 \text { and } 3 \text { and } 4 \\
\text { PubMed: } \\
\text { 1. (canine or canines or dog or dogs) } \\
\text { 2. (anaesthesia or anesthesia or anaesthetic or anesthetic) } \\
\text { 3. (gastroprotectant or gastro-protectant or protectant or } \\
\text { omeprazole or esomeprazole or cisapride or maropitant or } \\
\text { metoclopramide or ranitidine) } \\
\text { 4. ((gastro or gastric) and reflux) or GOR or GER } \\
5.1 \text { and } 2 \text { and } 3 \text { and } 4\end{array}$ \\
\hline Dates searches performed: & 14 May 2020 \\
\hline
\end{tabular}

Exclusion / Inclusion Criteria

Exclusion: Studies that did not include anaesthesia, were not English, wrong species or were not related to PICO

Inclusion: Peer-reviewed journals, veterinary journals, full papers, dogs 


\begin{tabular}{|l|c|c|c|c|c|c|}
\hline \multicolumn{5}{|l|}{ Search Outcome } \\
\hline Database & $\begin{array}{r}\text { Number } \\
\text { of } \\
\text { results }\end{array}$ & $\begin{array}{r}\text { Excluded - } \\
\text { Not peer- } \\
\text { reviewed }\end{array}$ & $\begin{array}{c}\text { Excluded - Did } \\
\text { not answer the } \\
\text { PICO question }\end{array}$ & $\begin{array}{c}\text { Excluded - } \\
\text { Anything other } \\
\text { than veterinary } \\
\text { journals }\end{array}$ & $\begin{array}{c}\text { Excluded - Not } \\
\text { in English }\end{array}$ & $\begin{array}{c}\text { Total } \\
\text { relevant } \\
\text { papers }\end{array}$ \\
\hline $\begin{array}{l}\text { CAB } \\
\text { Abstracts }\end{array}$ & 9 & 1 & 3 & 0 & 0 & 5 \\
\hline PubMed & 10 & 0 & 6 & 0 & 0 & 4 \\
\hline
\end{tabular}

\section{CONFLICT OF INTEREST}

The author declares no conflicts of interest.

Acknowledgements - Dr Mary Fraser (BVMS CertVD PhD FHEA CBiol MIBiol FRCVS), Samantha Fontaine (MSc PGCAP BSc DipAVN(Med) RVN FHEA) and Dr Desiree Scott (BVM\&S MRCVS).

University of Glasgow - Post Graduate Certificate in Advanced Practice in Veterinary Nursing.

Clare Boulton (RCVS Knowledge) for her assistance with finalising the search strategy and the reviewers.

\section{REFERENCES}

1. Downing, F. \& Gibson, S. (2018). Anaesthesia of brachycephalic dogs. Journal of Small Animal Practice, 59(12), 725-733. DOI: https://doi.org/10.1111/isap.12948

2. Favarato, L. S. C., Favarato, E. S., Souza, M. V., Costa, P. R. S., Nehme, R. C., Monteiro, B. S. \& Bonfá, L. P. (2012). Evaluation of metoclopramide and ranitidine on the prevention of gastroesophageal reflux episodes in anesthetized dogs. Research in Veterinary Science, 93(1), 466-467.

DOI: https://doi.org/10.1016/j.rvsc.2011.07.027

3. Johnson, R. A. (2014). Maropitant prevented vomiting but not gastroesophageal reflux in anesthetized dogs premedicated with acepromazine-hydromorphone. Veterinary Anaesthesia and Analgesia, 41(4), 406-410. DOI: https://doi.org/10.1111/vaa.12120

4. Marks, S. L., Kook, P. H., Papich, M. G., Tolbert, M. K. \& Willard, M. D. (2018). ACVIM consensus statement: Support for rational administration of gastrointestinal protectants to dogs and cats. Journal of Veterinary Internal Medicine, 32(6), 1823-1840. DOI: https://doi.org/10.1111/jvim.15337

5. NOAH Compendium (NOAH). (2020). Emeprid, clinical particulars.

6. Panti, A., Bennett, R., Corletto, F., Brearley, J., Jeffrey, N. \& Mellanby, R. (2009). The effect of omeprazole on oesophageal pH in dogs during anaesthesia. Journal of Small Animal Practice, 50(10), 540-544. DOI: https://doi.org/10.1111/j.1748-5827.2009.00818.x

7. Rodríguez-Alarcón, C., Beristain-Ruiz, D., Rivera-Barreno, R., Díaz, G., Usón-Casaús, J., García-Herrera, R., Pérez-Merino, E., Universidad Autónoma de Ciudad Juárez \& Universidad de Extremadura. (2015). 
Gastroesophageal reflux in anesthetized dogs: a review. Revista Colombiana de Ciencias Pecuaria, 28(2), 144-155. DOI: https://doi.org/10.17533/udea.rccp.v28n2a03

8. Wilson, D., Evans, A. \& Mauer, W. (2006). Influence of metoclopramide on gastro-esophageal reflux in anesthetized dogs. American Journal of Veterinary Research, 67(1), 26-31.

DOI: https://doi.org/10.2460/ajvr.67.1.26

9. Wilson, D., Evans, A. \& Miller, R. (2005). Effects of preanesthetic administration of morphine on gastroesophageal reflux and regurgitation during anesthesia in dogs. American Journal of Veterinary Research, 66(3), 386-390. DOI: https://doi.org/10.2460/ajvr.2005.66.386

10. Zacuto, A. C., Marks, S. L., Osborn, J., Douthitt, K. L., Hollingshead, K. L., Hayashi, K., Kapatkin, A. S., Pypendop, B. H. \& Belafsky, P. C. (2012). The Influence of Esomeprazole and Cisapride on Gastroesophageal Reflux During Anesthesia in Dogs. Journal of Veterinary Internal Medicine, 26(3), 518-525. DOI: https://doi.org/10.1111/i.1939-1676.2012.00929.x 


\section{EVIIDEFeE

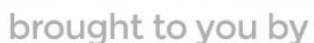 \\ RCVS KNOWLEDGE}

\section{Intellectual Property Rights}

Authors of Knowledge Summaries submitted to RCVS Knowledge for publication will retain copyright in their work, and will be required to grant RCVS Knowledge a non-exclusive license of the rights of copyright in the materials including but not limited to the right to publish, re-

publish, transmit, sell, distribute and otherwise use the materials in all languages and all media throughout the world, and to license or permit others to do so.

\section{Disclaimer}

Knowledge Summaries are a peer-reviewed article type which aims to answer a clinical question based on the best available current evidence. It does not override the responsibility

of the practitioner. Informed decisions should be made by considering such factors as individual clinical expertise and judgement along with patient's circumstances and owners' values. Knowledge Summaries are a resource to help inform and any opinions expressed within the Knowledge Summaries are the author's own and do not necessarily reflect the view of the RCVS Knowledge. Authors are responsible for the accuracy of the content. While the

Editor and Publisher believe that all content herein are in accord with current recommendations and practice at the time of publication, they accept no legal responsibility

for any errors or omissions, and make no warranty, express or implied, with respect to material contained within.

For further information please refer to our Terms of Use.

RCVS Knowledge is the independent charity associated with the Royal College of Veterinary Surgeons (RCVS). Our ambition is to become a global intermediary for evidence based veterinary knowledge by providing access to information

that is of immediate value to practicing veterinary professionals and directly contributes to evidence based clinical decision-making.

\section{https://www.veterinaryevidence.org/}

RCVS Knowledge is a registered Charity No. 230886.

Registered as a Company limited by guarantee in England and Wales No. 598443.

Registered Office: Belgravia House, 62-64 Horseferry Road, London SW1P 2AF

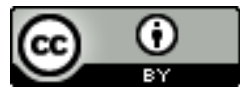

This work is licensed under a Creative Commons Attribution 4.0 International License 